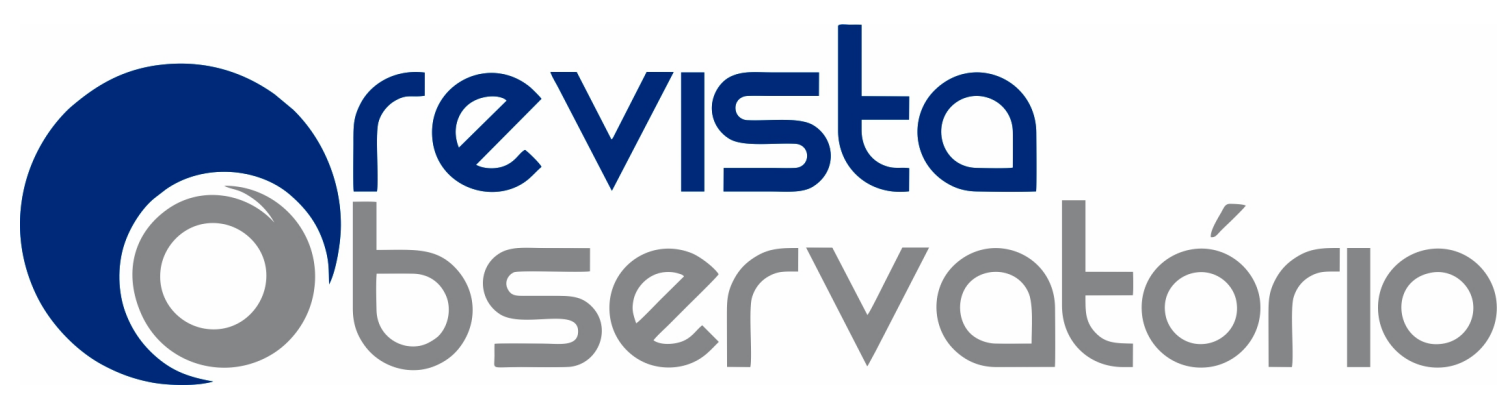

\section{INFLUÊNCIA MIDIÁTICA NA CONDENAÇÃO POPULAR ANTECIPADA}

MEDIA INFLUENCE ON EARLY POPULATION CONDEMNATION

INFLUENCIA MEDIÁTICA EN LA CONDENA TEMPRANA DE LA POBLACIÓN

\author{
Érika Souza ${ }^{1}$ \\ Igor Andrade Barbosa ${ }^{2}$ \\ Valdirene Cássia da Silva ${ }^{3}$
}

\title{
RESUMO
}

Este artigo relaciona a mídia social e sua intervenção na opinião do povo brasileiro, especialmente em relação aos casos que causam notória comoção pública. Serão abordadas questões como a liberdade de expressão, a evolução histórica da mídia, o papel social da imprensa e da notícia, bem como, o direito ao esquecimento. Ademais, foi realizada uma análise crítica dos estereótipos midiáticos nas notícias de crimes e sua participação na condenação pública antecipada do acusado e as consequências nas relações processuais penais. A metodologia utilizada foi qualitativa e analítica, tendo a revisão da literatura específica o principal instrumento de coleta de dados. Os resultados aduzem que

\footnotetext{
${ }^{1}$ Centro Universitário Católica do Tocantins. E-mail: erikasimara88@gmail.com.

2 Defensor Público Federal na Defensoria Pública da União no Estado do Tocantins. Mestre em Direito Econômico e Desenvolvimento pelo Programa de Mestrado em Direito da Universidade Candido Mendes UCAM. Professor da graduação e da pós-graduação do curso de Direito da Faculdade Católica do Tocantins - UBEC. E-mail: igor.barbosa@catolica-to.edu.br.

3 Doutora e Mestre em Educação pela Universidade Federal da Bahia. Especialista em Comunicação, Estratégias e linguagens. Graduada em Comunicação Social, habilitação em Relações Públicas. Atualmente é professora titular da Universidade Luterana de Palmas Ceulp/Ulbra e Faculdade Católica do Tocantins - FACTO. E-mail: valdirene.silva@catolicato.edu.br.
} 


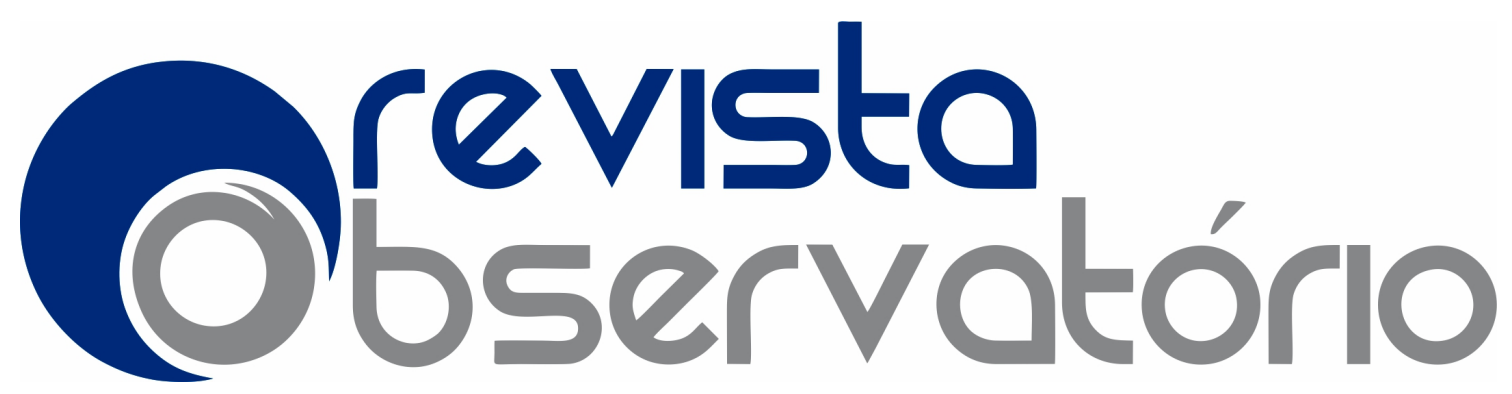

ISSN n² 2447-4266

Vol. 5, n. 6, Outubro-Dezembro. 2019

DOI: http://dx.doi.org/10.20873/uft.2447-4266.2019v5n6p429

a obsessão midiática induz à retaliação pública e a limitação dos direitos fundamentais dos protagonistas, apesar do resultado da sentença judicial.

PALAVRAS-CHAVE: Impacto da comunicação. Opinião pública. Liberdade de expressão. Direito Penal. Direito a um processo imparcial.

\section{ABSTRACT}

This article relates social media and its intervention in the opinion of the Brazilian people, especially in relation to cases that cause notorious public commotion. Issues such as freedom of expression, the historical evolution of the media, the social role of the press and news, as well as the right to forget will be addressed. In addition, a critical analysis of media stereotypes in crime news and their participation in the early public conviction of the accused and the consequences on criminal procedural relations was conducted. The methodology used was qualitative and analytical, with the literature review being the main instrument for data collection. The results add that the media obsession induces public retaliation and the limitation of the protagonists' fundamental rights, despite the outcome of the court ruling.

KEYWORDS: Communication impact. Public opinion. Freedom of expression. Criminal law. Right to a fair trial.

\section{RESUMEN}

Este artículo relaciona las redes sociales y su intervención en la opinión del pueblo brasileño, especialmente en relación con casos que causan conmoción pública notoria. Se abordarán cuestiones como la libertad de expresión, la evolución histórica de los medios de comunicación, el papel social de la prensa y las noticias, así como el derecho al olvido. Además, se realizó un análisis crítico de los estereotipos de los medios en las noticias sobre delitos y su participación en la condena pública temprana del acusado y las consecuencias sobre las relaciones procesales penales. La metodología utilizada fue cualitativa y analítica, siendo la revisión de la literatura el principal instrumento para la recopilación de datos. Los resultados agregan que la obsesión de los medios induce represalias 


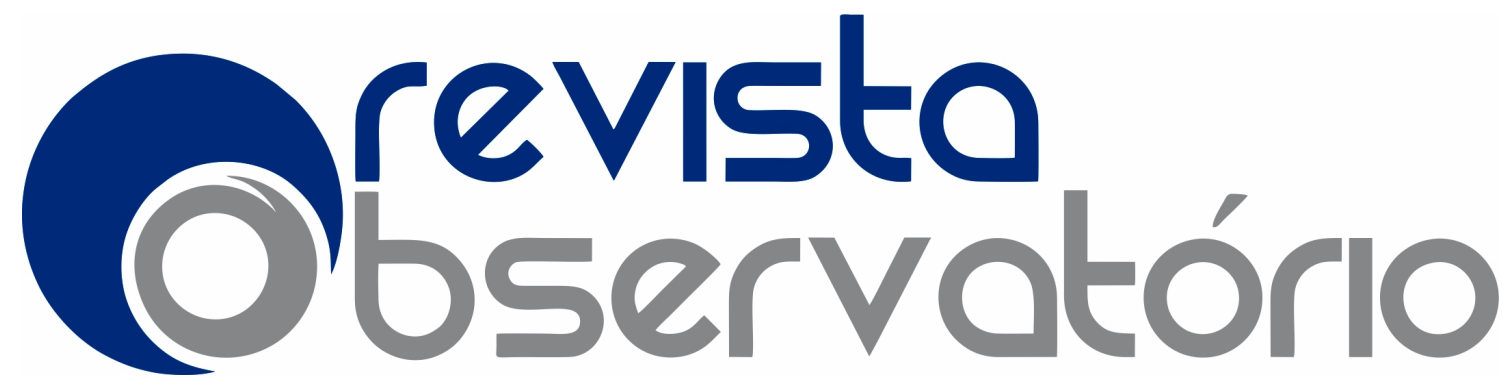

ISSN n² 2447-4266

Vol. 5, n. 6, Outubro-Dezembro. 2019

DOI: http://dx.doi.org/10.20873/uft.2447-4266.2019v5n6p429

públicas y la limitación de los derechos fundamentales de los protagonistas, a pesar del resultado del fallo judicial.

Palabras clave: Impacto de la comunicación. Opinión pública. Libertad de expresión. Derecho penal. Derecho a un proceso imparcial.

Recebido em: 01.06.2019. Aceito em: 09.09.2019. Publicado em: 01.10.2019. 


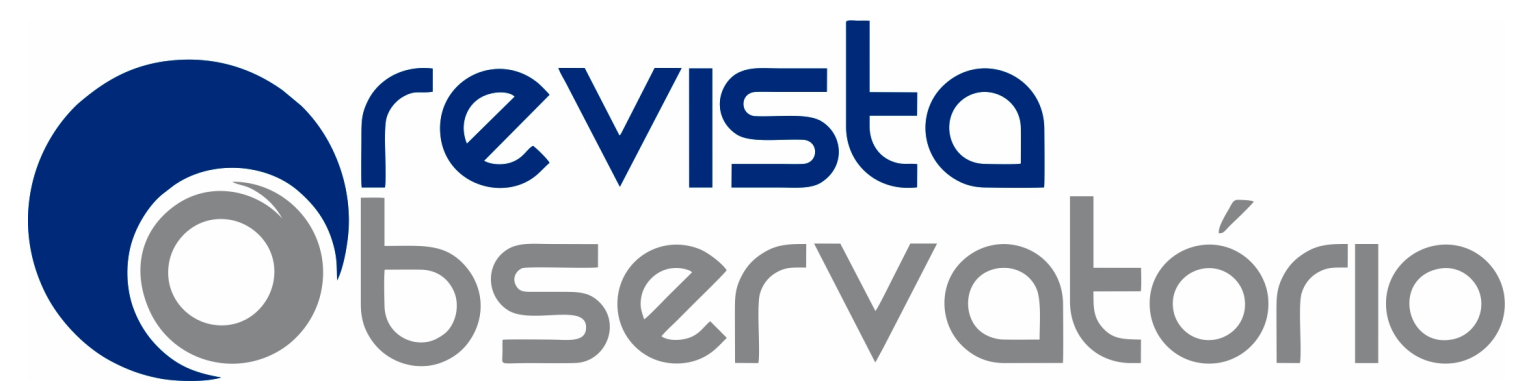

ISSN n² 2447-4266

Vol. 5, n. 6, Outubro-Dezembro. 2019

DOI: http://dx.doi.org/10.20873/uft.2447-4266.2019v5n6p429

\section{Introdução}

O direito à informação, à liberdade de expressão e manifestação do pensamento está elencado no rol de diretos e garantias fundamentais da Constituição da República Federativa do Brasil (CRFB) de 1988 em seu art. 5, inc. IV e XIV. Esses direitos assegurados pela Carta Magna permitem a disseminação de notícias pelos diversos meios de comunicação, fazendo com que a população seja informada dos fatos do Brasil e do mundo.

As informações que são transmitidas necessitam de imparcialidade, mesmo que a mídia almeje lucro por ser uma empresa. É a partir do que se transmite na mídia que cidadãos passam a acreditar nas matérias exibidas, nos mais diversos meios de comunicação que possuem em suas residências, gerando a partir deste instante as formulações dos padrões que visam à homogeneidade da social, julgamentos, condenações e absolvições antecipadas de pessoas envolvidas nos fatos noticiados.

Ressalta-se que na ocasião de exteriorização dos delitos incide a opinião do jornalista, ou seja, a notícia exposta pode nem sempre corresponder na íntegra a realidade, mas no meio social todos acreditam fielmente no que ouve e lê, condição propícia para a manipulação, apossam-se dos fatos como se fossem totalmente verdadeiros.

A dominação dos fatos e a influência perante o povo atinge não apenas os suspeitos/réus de crimes, mas os que giram ao seu entorno, instituindo ao poder judiciário a obrigação de aplicar sanções rápidas e severas com a finalidade de satisfazer a ânsia de justiça dos agrupamentos sociais.

O conjunto de estereótipos produzidos pela mídia mesmo de forma indireta, produz na sociedade o desejo de vingança já intrínseco no ser humano. Descrever crime é quase um sinônimo de comoção social resultante dos acontecimentos com as vítimas, e extremo fascínio pela punição a ser arrolada a 


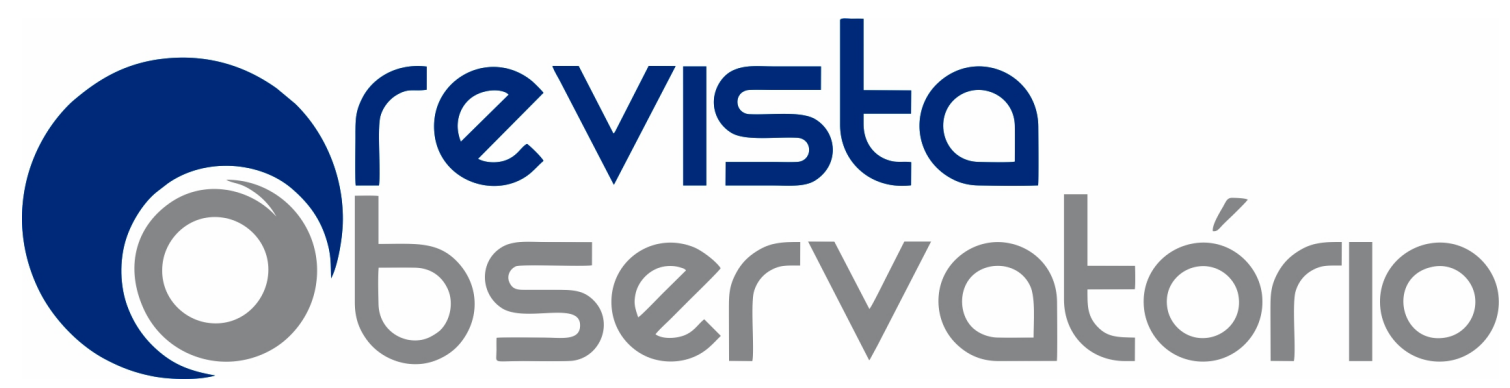

DOI: http://dx.doi.org/10.20873/uft.2447-4266.2019v5n6p429

mais um indivíduo encarcerado pagando por aquilo que se suspeita ser real correto a acordo com os padrões sociais.

Envolver os padrões de um corpo social e o sistema penal, não quer dizer que haverá uma participação efetiva da transação criminal apenas, mas indiretamente ações diretas na questão financeira e emocional do Estado e da população.

É fácil notar a influência da massa quando as notícias tornam -se frequentes, incisivas e condenadoras sobre assuntos diversos. Rotineiramente temos um círculo de especulações e espetacularizações de fatos criminais, personalidades de suspeitos, histórico de suas vidas, família, amigos circundam incessantemente em torno da situação e de seus resultados.

A indagação pela compreensão da espetacularização da pena e dos réus perante a população e o judiciário nos leva a produção da presente pesquisa, apropria-se da realidade para analisá-la, e, posteriormente, produzir transformações, além do aspecto prático relevante, reveste-se de importância para o meio acadêmico.

Neste contexto, grande parte da produção dos estudos e conteúdo poderá ser o início de modificações que começam na vida acadêmica e dar-se continuidade no grupo social na qual estamos inseridos.

Assim sendo, este trabalho procurou, através da pesquisa, compreender o impacto da imprensa diante a vida de pessoas suspeitas e/ou condenadas por diversos delitos.

\section{Histórico da Espetacularização da Pena Desde o Século XIX}

No histórico da condenação e espetacularização da pena, é importante ressaltar os principais aspectos que envolveram a sua incidência. Julgar e punir, desde o século $V$, era dever dos senhores detentores da obrigação de serem 


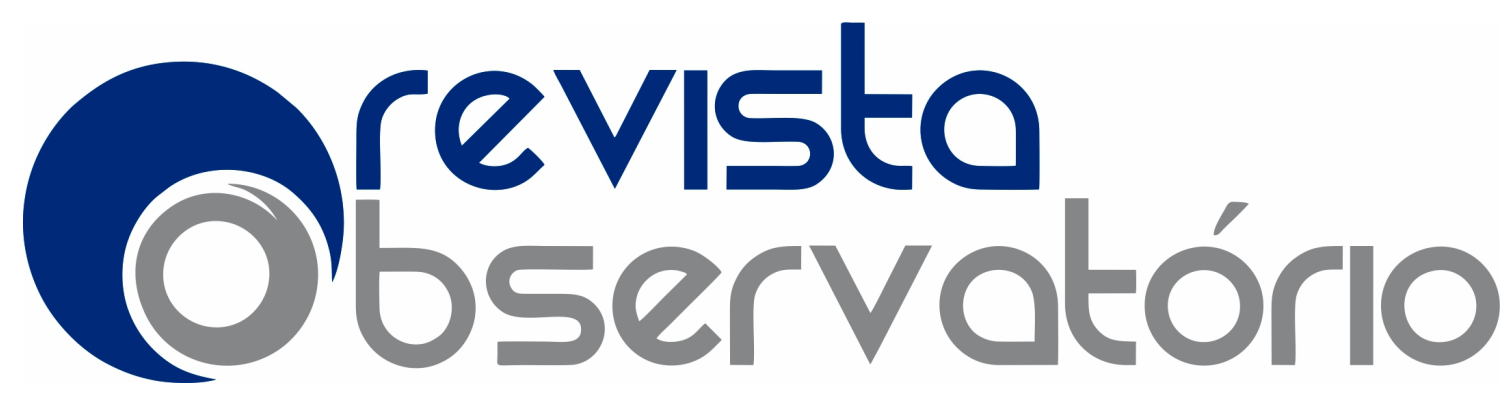

ISSN n² 2447-4266

Vol. 5, n. 6, Outubro-Dezembro. 2019

DOI: http://dx.doi.org/10.20873/uft.2447-4266.2019v5n6p429

representantes da sociedade, com os anos suas necessidades os fizeram desenvolver formas de julgar e punir, expondo as provas quando as tinham, demonstravam regras estabelecidas em conjunto e condições a serem cumpridas aos que infringissem as normas impostas a época.

O escritor Beccaria (1999) acreditava que a pena privativa de liberdade começara no século XVIII. No entanto, Foucault (2014) sempre defendeu que o ato de punir através do encarceramento do indivíduo começou no século XIX. De acordo com este último autor, as punições públicas dos condenados aconteciam com destacada crueldade e frieza.

[Damiens fora condenado, a 2 de março de 1757], a pedir perdão
publicamente diante da poria principal da Igreja de Paris [aonde devia
ser] levado e acompanhado numa carroça, nu, de camisola, carregando
uma tocha de cera acesa de duas libras; [em seguida], na dita carroça,
na praça de Greve, e sobre um patíbulo que aí será erguido, atenazado
nos mamilos, braços, coxas e barrigas das pernas, sua mão direita
segurando a faca com que cometeu o dito parricídio, queimada com
fogo de enxofre, e às partes em que será atenazado se aplicarão
chumbo derretido, óleo fervente, piche em fogo, cera e enxofre
derretidos conjuntamente, e a seguir seu corpo será puxado e
desmembrado por quatro cavalos e seus membros e corpo consumidos
ao fogo, reduzidos a cinzas, e suas cinzas lançadas ao vento.
(FOUCAULT, 2014, p. 9).

Os Tratados e Convenções Internacionais, há alguns anos, vem inserindo a proteção ao indivíduo e a preservação do princípio fundamental da dignidade da pessoa humana. Ao fim da Segunda Guerra Mundial houve grandes avanços, criou-se a Organização das Nações Unidas, logo após Declaração dos Direitos dos Homens. Foi um marco mundial na nova era da aplicação das penas.

No Brasil, a Constituição Federal de 1988 declarou expressamente os limites a serem seguidos na aplicação da penalidade justa e sem abusos a integridade física e moral do indivíduo, estes estão descritos nos artigos $5^{\circ}$, inciso XLVII e XLIX e $8^{\circ}$, XIX, e quando nos deparamos com o Código Penal Brasileiro, 


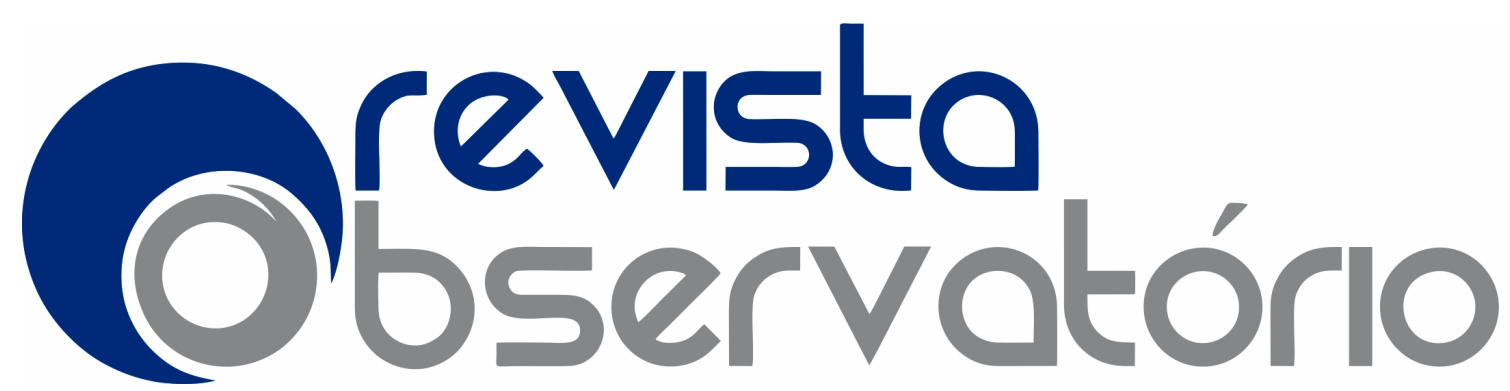

este afirma ser imprescindível um meio necessário e suficiente para a reprovação, mas também de prevenção dos crimes.

De fato, cumprir sua dívida com a sociedade é de fundamental importância, nota-se claramente essa necessidade, o que é preocupante são os liames de influência da mídia neste sistema punitivo leigo da massa.

O grande problema, entretanto, dar-se-á pelo "o próprio sistema punitivo fazer parte do sistema de comunicação social" (CARVALHO FILHO, 2003, p.226). A comunicação pública caminhava na mesma direção, a vingança de um grupo instigada pelos meios de comunicação que partia do seguinte pensamento:

Concebia-se o fenômeno criminal como uma realidade ontológica préconstituída à reação social, isto é, como algo que existe per se. $\mathrm{Na}$ incessante busca pela causa da delinquência, algo intrinsecamente mau, os positivistas em linhas gerais patologizaram o fenômeno delituoso, subvalorizaram o encontro social e formularam conclusões pré-maturas. (SHECARIA, 2004, p. 128).

Os séculos foram passando e pouca coisa mudou, temos a mídia como o quarto poder, isso atribuído a grande participação nos fenômenos delituosos e sociais da massa. Nos séculos passados, havia demonstrações de esquartejamentos, enforcamentos e decapitações, na atualidade temos notícias e reportagem que podem condenar, punir, julgar ou absolver.

\section{Princípio da Presunção de Inocência}

Os meios de comunicação em massa, muito comuns na contemporaneidade, fazem o povo chorar, sorrir e chocar com acontecimentos diários, de forma que o apresentador, como principal fonte de informação, possui grande influência na formação da opinião pública. 


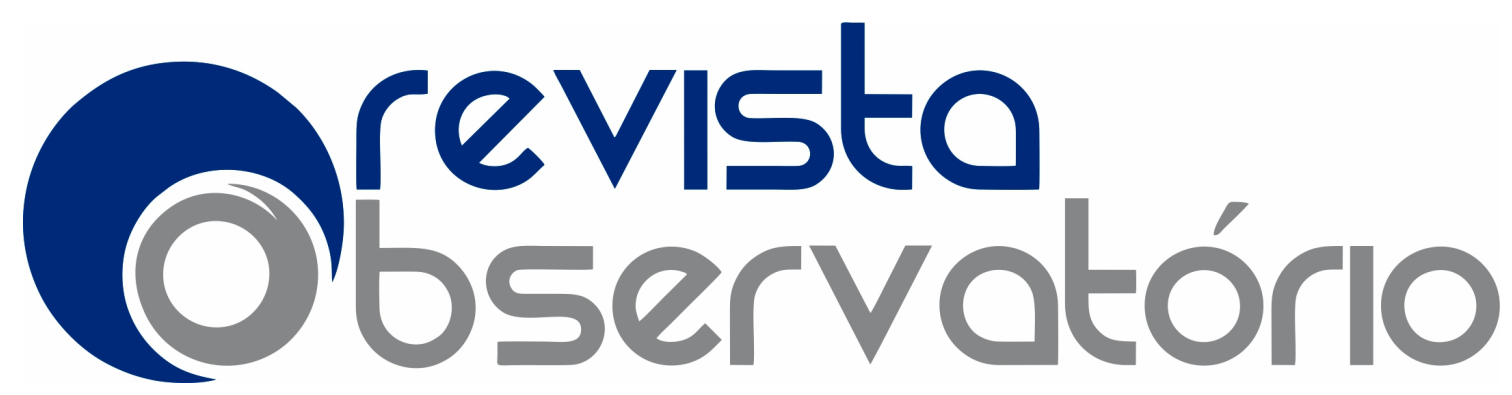

ISSN n² 2447-4266

Vol. 5, n. 6, Outubro-Dezembro. 2019

DOI: http://dx.doi.org/10.20873/uft.2447-4266.2019v5n6p429

Os crimes noticiados de grandes repercussões são acompanhados de duras críticas, aversão, revolta, e desprezo com o fato da possível impunidade do suspeito e do sistema penal. Na maioria das vezes aqueles que se expressam através das mídias não possuem nenhum conhecimento jurídico nas esferas penais e processuais penais.

Se perguntássemos para a população qual é o tratamento mais adequado para quem sofreu um aneurisma, claro que o cidadão comum diria: 'não tenho a mínima ideia'. Com certeza, ademais, nunca diria que um curandeiro seria a pessoa indicada para solucionar o problema citado. Sobre o mundo da medicina complexa o indivíduo comum não costuma opinar, por falta de conhecimento específico. Não é isso que acontece, no entanto, no campo da criminalidade. Todo mundo, incluindo, portanto, os jornalistas, tem sempre uma receita (infalível) para a 'cura' desse 'mal'. Prisão, castigo duro, humilhação, degradação do preso, abolição das garantias penais, tortura, extermínio etc. (GOMES, 2013, p. 104).

As empresas de grande veiculação e repercussão abrem espaço ao espetáculo punitivo das pessoas, gerando vigilância constante da vida pública. Assim, não existe privacidade do sujeito detentor do direito de uma presunção constitucional de inocência.

O grupo social coloca de um lado o desejo de encarcerar os infratores em prisões superlotadas e de outro lado o Estado representado pelo poder judiciário, que detêm as forças necessárias no intuito de cumprir a legislação. Haja vista, que o interesse de agir dos meios de informação fazem o julgamento antes do devido processo legal, eles não obtêm qualificação das jurisprudências que serão utilizadas na decisão final.

Não se pode esquecer que ainda falta uma preparação específica e uma adequada deontologia profissional para alguns jornalistas. $\mathrm{O}$ clamor público desencadeado pela prática de um crime hediondo pode resultar da exploração distorcida dos fatos por um mal-intencionado meio de comunicação que busca mover a consciência e a vontade dos membros da sociedade numa direção predeterminada. (SOUZA NETTO, 2011, p. 74). 


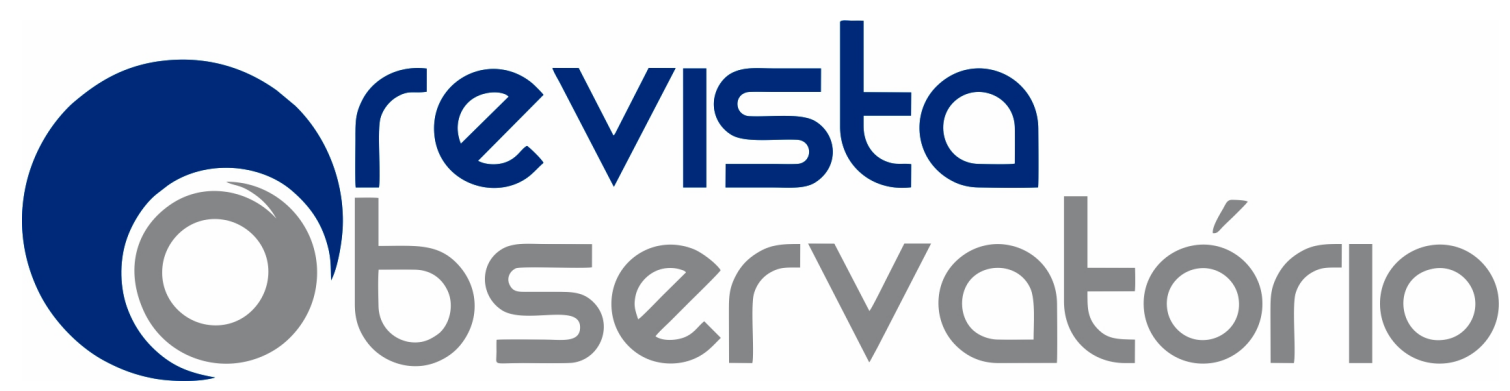

ISSN n² 2447-4266

Vol. 5, n. 6, Outubro-Dezembro. 2019

DOI: http://dx.doi.org/10.20873/uft.2447-4266.2019v5n6p429

As fontes de transmissão de informações dissipam notícias, por vezes, dissociadas dos fatos e circunstâncias que motivaram determinada ação, de forma torna quase impossível para a audiência elaborar seus próprios argumentos quanto às informações para tirarem suas próprias conclusões, haja vista que apenas sabem o que the mostrado.

É importante destacar que várias são as normas que possibilitam fundamentar e expor a presunção de inocência nas redes de comunicação em massa. Entre elas podemos ressaltar a Constituição da República Federativa do Brasil de 1988 que em seu art. 5, LVII, relata que "ninguém será considerado culpado até o trânsito em julgado de sentença penal condenatória".

De igual modo, a Declaração Mundial sobre Direitos do Homem, artigo 6. 11, ficou acordado que o ser humano que for acusado de ato delituoso será inocente até que sua culpabilidade seja provada e que todos as suas garantias necessárias sejam asseguradas, em outras palavras todos os meios técnicos e jurídicos darão esta base para comprovação.

Por sua vez, a Convenção Americana sobre Direitos Humanos (CADH) Assinada na Conferência Especializada Interamericana sobre Direitos Humanos, San José, Costa Rica, em 22 de novembro de 1969, em seu artigo $8^{\circ}$ confirma os mesmos entendimentos sobre a presunção de inocência, o devido processo legal e a comprovação da culpabilidade são assegurados a pessoa acusada de cometer ato delituoso.

Consequentemente, nota-se que os fundamentos jurídicos não são vagos e de difícil entendimento pelos jornalistas e disseminadores de informações. Dessa forma, observa-se que as informações transmitidas pela mídia poderiam expor os fatos e o embasamento legal simultaneamente, mesmo que de forma simplória, para que a população tivesse o mínimo de visão da jurisprudência e do processo legal. 


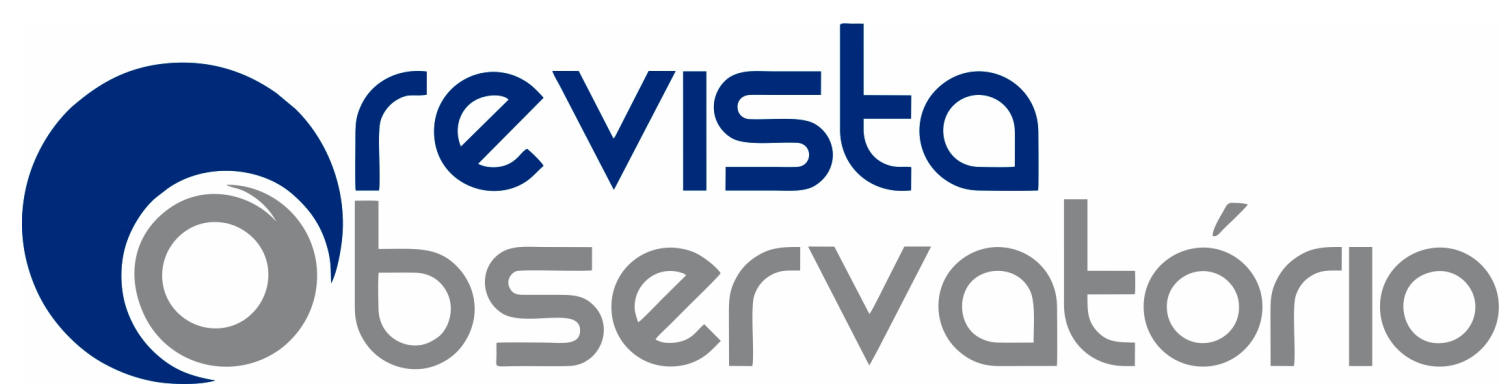

ISSN n² 2447-4266

Vol. 5, n. 6, Outubro-Dezembro. 2019

DOI: http://dx.doi.org/10.20873/uft.2447-4266.2019v5n6p429

Desta forma, relações distantes entre os suspeitos por vezes leigas e sentença antecipada em relação em relações em que há uma interferência na vida do indivíduo. Podemos ir além com a fundamentação de Freud "os homens não são criaturas gentis [...], pelo contrário, são criaturas entre cujos dotes instintivos, devem-se levar em conta uma poderosa quota de agressividade" (FREUD, 2010, p. 28).

Os sujeitos detentores relações espontâneas de violência não se preocupam a desestruturação que pode causar diante do que a mídia expõe, segundo o autor supracitado:

A existência da inclinação para a agressão, [...] constitui o fator que
perturba nossos relacionamentos com o nosso próximo e força a
civilização a um tão elevado dispêndio (de energia). Em consequência
dessa mútua hostilidade primária dos seres humanos, a sociedade
civilizada se vê permanentemente ameaçada de desintegração (FREUD,
2010, p. 29).

A produção estereótipos positivos e negativos é incorporada na população com o emaranhado de informações culturais, estes circulam em meio aos sistemas de disseminação de mensagens de todos os conteúdos informativos. O que faz culpável o ser humano não é ter praticado fato concreto, mas, unicamente, ser quem ele é, dado que se converte, portanto, no objeto central a condenação e julgamento da sociedade, que castiga não simplesmente pelo que fez, mas por quem é diante do crime (PELUSO, 2015, p. 209).

A verdade das informações também é maquiada pelos jornalistas quando estes imprimem a essas as suas impressões, sensações e opiniões (CHAUÍ, 2006, p. 57).

Assim, várias reportagens veiculadas pelos mais distintos programas e redes de televisivas; dezenas de manchetes e chamadas em jornais impressos e edições virtuais; inúmeras matérias de capa das principais revistas semanais, 


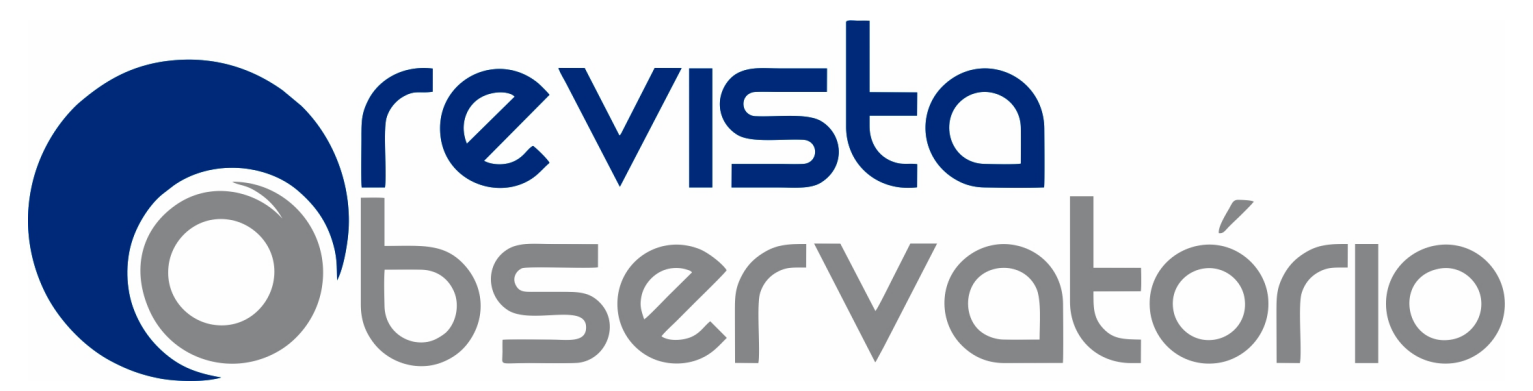

ISSN n² 2447-4266

Vol. 5, n. 6, Outubro-Dezembro. 2019

DOI: http://dx.doi.org/10.20873/uft.2447-4266.2019v5n6p429

destacando os eventos que chamam a atenção da população, que podem ser sangrentos e violentos, os sujeitos dos casos possivelmente não terão outro desfecho senão a penalidade rígida do poder judiciário.

\section{Condenação Penal e Condenação Midiática}

O ordenamento jurídico pátrio prevê a necessidade de o Estado acusador comprovar a culpabilidade do indivíduo, sendo assegurado constitucionalmente ao acusado o contraditório e a ampla defesa, não se admitindo o afastamento de direitos e garantias individuais e a imposição de sanções sem o devido processo legal. É a garantia de que nenhuma pessoa sofrerá os efeitos de uma sentença sem que tenha sido the dada a possibilidade de uma efetiva participação na formação da decisão judicial.

Há enumerações de alguns princípios garantidores de direitos mínimos do acusado, afirmando que estes devem nortear tanto o processo penal quanto o direito penal. Para o jurista Luigi Ferrajoli (2002, p.38), em sua obra clássica Direito e Razão a observância, esses princípios legitimariam a punição ao condenado, haja vista que o poder de punir deve ser limitado por regras claras.

O devido processo legal é o princípio do direito penal de que nula poena sine iudicio, ou seja, não há pena sem processo (ALVIM ,1999, p. 64). Significa, em outras palavras, que nenhuma sanção penal pode ser imposta sem a intervenção do juiz natural e mediante o devido processo.

A condenação pela prática de um ato ilícito penal implica em uma sanção prevista em lei, podendo ser de reclusão, detenção, prisão simples, restritivas de direitos e multa. A condenação criminal, todavia, possui outros efeitos penais secundários, tanto de natureza penal como de caráter extrapenal. Vale ressaltar que as sanções penais vão além do cárcere individual, propaga-se nos que estão circundados ao réu de diversas formas. 


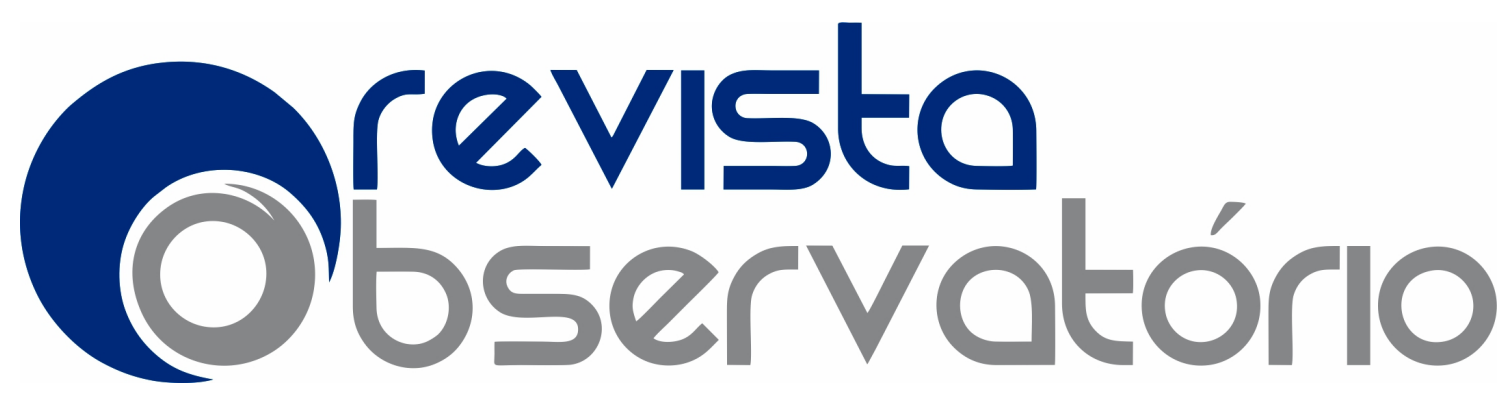

ISSN n² 2447-4266

Vol. 5, n. 6, Outubro-Dezembro. 2019

DOI: http://dx.doi.org/10.20873/uft.2447-4266.2019v5n6p429

Em sentido diametralmente oposto tem-se a condenação decorrente do clamor social. A expressão "clamor social" pode ser definida como o descontentamento, a indignação ou comoção no meio social resultante da prática de crimes em circunstâncias especiais causadoras dessa repercussão. Tem sido recorrente, na atualidade, os casos de crimes que causam comoção social. É preocupante a influência da mídia em relação as massas que impõem um ideal de criminalidade, punição e julgamento precedido de vingança, sem analisar os direitos fundamentais dos indivíduos como citado anteriormente.

O Supremo Tribunal Federal (STF), já decidiu que o pedido da sociedade não são meios para o consentimento de uma prisão preventiva legal temos a citar como exemplo o HC: 94554/BA, que possui como relator, o ministro Ricardo Lewandowski (STF). Os tribunais possuem sua autonomia em decisões, no entanto a Suprema Corte conclui o que seja melhor para manter a ordem social.

Em contrapartida, evidenciamos o Recurso Ordinário em Habeas Corpus julgado pelo Superior Tribunal de Justiça (STJ): RHC 1412643-05.2017.8.12.0000 sendo o relator é Min. Reynaldo Soares da Fonseca, nega a revogação da prisão preventiva do réu com base nos artigos 312 e 313 do Código de Processo Penal. A legislação descreve a garantia da ordem pública, em outras palavras, súplica por uma justiça dentre os padrões impostos por pessoa.

\section{Processo de Construção das Notícias}

A palavra "notícia" origina-se do latim "notitia"que significa notoriedade, noção, conhecimento de alguém. Notícia é qualquer informação sobre um fato novo ou divulgação de uma situação já existente de interesse público, este ocorrido no Brasil ou no mundo. 


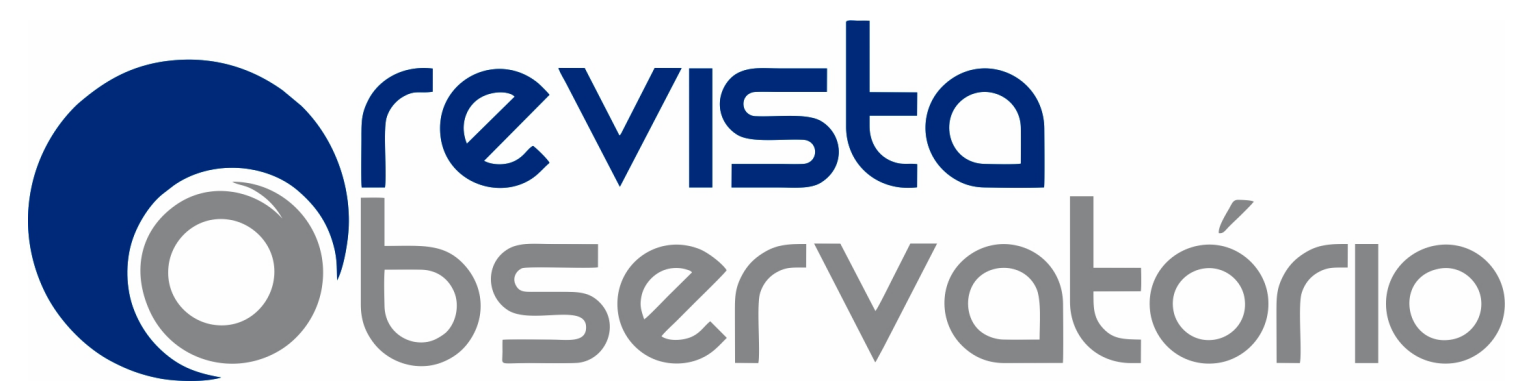

ISSN n² 2447-4266

Vol. 5, n. 6, Outubro-Dezembro. 2019

DOI: http://dx.doi.org/10.20873/uft.2447-4266.2019v5n6p429

Na mídia, a notícia é caracterizada por um texto ou imagem de caráter informativo, cujo conteúdo é extremamente diversificado podendo ser de cunho político, social, cultural, econômico e descritor de um crime.

Toda narração e descrição dos fatos contidos nos conteúdos devem ser exatos, objetivos e imparciais. Para que os deveres supracitados entrem no processo de construção das informações midiáticas, algumas perguntas requerem respostas, são elas: o que?, quem?, quando?, onde?, por quê?, como?.

Para obter respostas de tais indagações são necessárias de maneira organizada, natural, sem influência ou adulteração, um olhar minucioso e extremamente profissional daquele que dará abertura midiática a uma nova história a ser divulgada. As etapas deste processo de construção da notícia iniciam-se com o jornalista a ser encaminhado ao local do fato, a qual produzirá um relatório detalhado do ocorrido, ele possuirá textos, imagens e/ou fotografias, áudios e tudo que for indispensável para sua produção com a maior qualidade possível. Neste momento, logo após a coleta de dados e relatório, sua visão profissional seleciona e foca no que será o mais atrativo aos telespectadores, leitores e internautas, ou seja, ao povo.

O material coletado no local do fato e as informações contidas no relatório do jornalista ou no produtor da mídia, é analisado e discutido por uma equipe diversificada que decidirá sobre a publicação ou não da matéria.

Após a análise do conteúdo, este será editado e lapidado para que fique com escrita de qualidade, som e imagem ao público-alvo tornando interessante e atrativo. Quando o conteúdo midiático é finalizado inicia-se o processo de manipulação da população, este processo nada mais é do que o valor econômico do meio veiculador expositivo pois é uma empresa e visa o lucro sem se preocupar com as consequências de uma notícia sensacionalista, acusatória e que instiga o julgamento antecipado de uma população. 


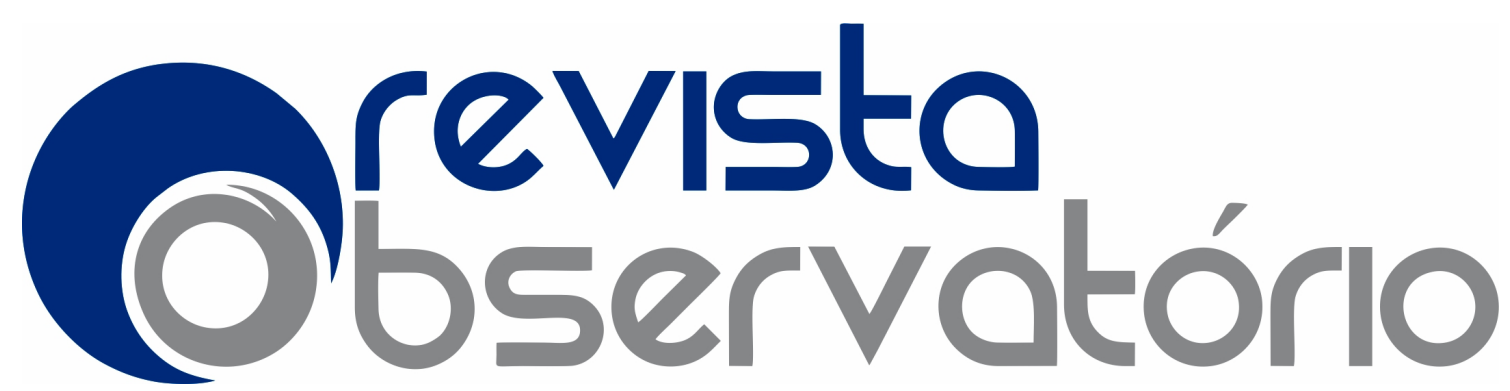

ISSN n² 2447-4266

Vol. 5, n. 6, Outubro-Dezembro. 2019

DOI: http://dx.doi.org/10.20873/uft.2447-4266.2019v5n6p429

Divulgadores de notícias são cidadãos conscientes dos seus atos. Ir procura dos melhores furos de reportagem, manchetes em jornais, divulgações em todas as redes sociais é um salto para o sucesso em sua profissão, mas isto não thes permite esconder fatos, manipulam ou produzem especulações, adulterar dados e encorajar condenações e julgamentos daqueles envoltos no contexto fático do crime.

Mesmo a matéria passando por muitos filtros até a exposição a sociedade, pessoas envolvidas sofrem com essa divulgação em massa e acabam sendo condenados por ato não praticado por eles, vale lembrar que a legislação diz que numa condenação vai além do acusado. O doutrinário Oacyr Silva Mascarenhas aduz:

\begin{abstract}
A imprensa chama para si o papel de vigilância dos Poderes Executivo, Legislativo e Judiciário, tudo em função do banalizado interesse público. Ocorre que a Mídia não está se preocupando com interesse público e sim com o interesse do público. O que se pretende é maximizar lucros para as grandes corporações que comandam uma dezena de veículos de comunicação. O problema é que, apesar da falta de legitimidade, a Mídia vem, de fato, exercendo poderes que exorbitam da ótica constitucional. A forma como se manipula os indivíduos, a maneira seletiva de transmitir informações, as investigações e condenações sumárias e o seu poderio econômico e ideológico ensejam um comportamento midiático supraconstitucional. (MASCARENHAS, 2016).
\end{abstract}

A doutrina e legislação são transparentes em relação a mídia possuir grande influência no comportamento e manipulação social.

Ressaltando a temática dos direitos dos cidadãos temos o Enunciado 274 do Conselho da Justiça Federal (CJF) que teve aprovação na IV Jornada de Direito Civil, estabelece que havendo conflito entre a população possuir o direito à informação que thes é assegurado legalmente, com os direitos civis do cidadão é necessário um equilíbrio, visto que um direito não se sobressai a outro. Assim sendo, transcreve-se o referido enunciado: 


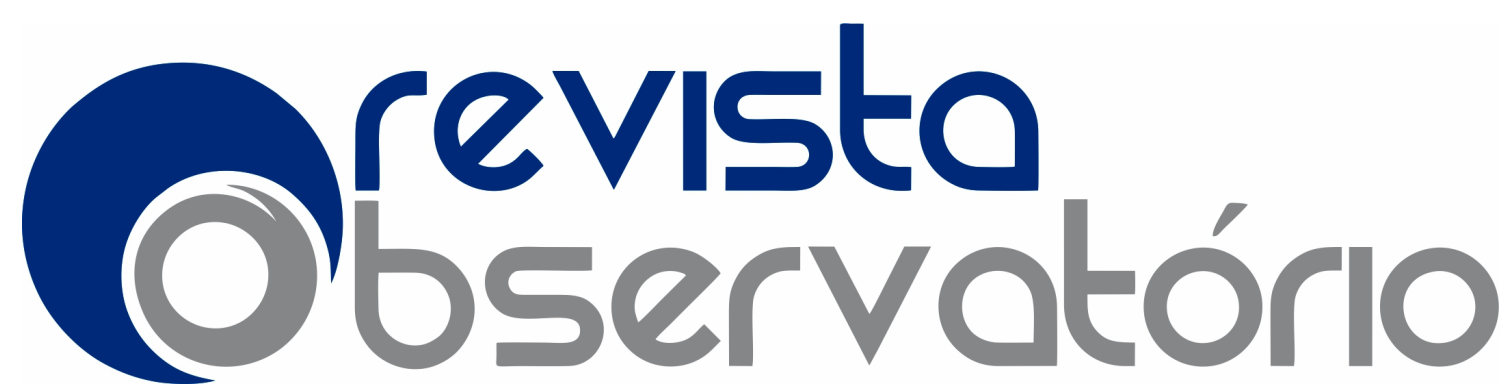

ISSN n² 2447-4266

Vol. 5, n. 6, Outubro-Dezembro. 2019

DOI: http://dx.doi.org/10.20873/uft.2447-4266.2019v5n6p429

Os direitos da personalidade, regulados de maneira não exaustiva pelo Código Civil, são expressões da cláusula geral de tutela da pessoa humana, contida no art. $1^{\circ}$, III da Constituição da República Federativa do Brasil determina que és princípio da dignidade da pessoa humana. Em caso de colisão entre eles, como nenhum pode sobrelevar aos demais, deve-se aplicar a técnica da ponderação.

Mensurar o equilíbrio entre a divulgação de informações, o direito a personalidade, presunção de inocência e ao esquecimento daqueles que são estereotipados como criminosos e condenados antecipadamente pela população não é tarefa fácil em um país como o Brasil, mas necessária para que injustiças não sejam cometidas nem no âmbito social e muito menos judiciário.

\section{O Reflexo da Mídia no Pensamento da População}

A comunicação em massa da vida moderna é adaptável, maleável, vulnerável e incapaz de manter suas formas originais e não conseguem se reforçar de acordo com o estado temporário das relações sociais.

Em sentido contrário, o legado de pessoas instantaneamente conectadas tende a elevar acontecimentos sem se preocupar com a veracidade, validade e influência da massa.

Noticiários sensacionalistas diários reforçam e tornam os acontecimentos em formas cruéis, mais do que já são, instigando o ódio que é presente por instintivamente nos seres humanos, Ariane Câmara Nery afirma:

As justificativas para essa atitude não encontram explicações lógicas nem legais, contudo, podemos inferir que pelo desejo social, a vingança popular se consuma com atos contra os réus, já naquele momento certamente estavam condenados pela opinião pública (NERY, 2010, p. $68)$.

Ou seja, a convicção apreciada é construída através da mídia que incentiva aos seus telespectadores, ouvintes ou web espectadores no 


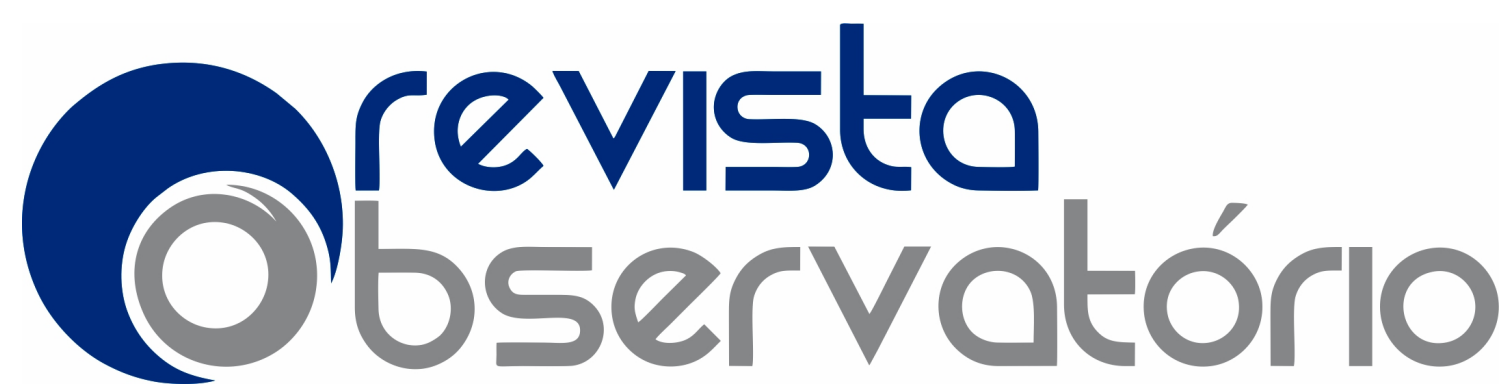

julgamento/condenação ou absolvição precipitada e despreparada de crimes antes do devido processo legal.

O foco das notícias é manter-se no auge da audiência sem permitir que seu conteúdo envelheça e a população esqueça dos fatos, sendo que exercem forte influência sobre o pensamento do indivíduo:

As ideias, reflexões e conceitos da maioria das pessoas são amparados, ou melhor, são frutos de uma relação entre as ideologias presentes na sociedade e convicções pessoais. As pessoas comunicam se e, cada vez mais, organizam seus pontos de vista, com isso muitas vezes formam suas opiniões e fazem suas escolhas com base no que lhes é informado através dos meios de comunicação (NUNES, 2008, p. 53).

Disseminar informações de certa maneira alienam as pessoas de tal modo que suas reflexões acontecem conforme thes é exposto no dia a dia pelos meios de comunicações midiático, sendo que estes já lhes ofertam pensamentos e concepções prontas e acabadas.

\section{Direito ao Esquecimento}

O direito ao esquecimento é inerente à pessoa, na qual não é permitido a este que um acontecimento, mesmo que verdadeiro, seja exposto a população sendo ignorado seu direito de deslembrança dos acontecimentos em que esteja ou esteve envolvido em alguma fase de sua vida.

Levando, então, em consideração que ter o fato esquecido é ter seu direito de estar em paz consigo e com a população que nos cerca, ou seja, fazer valer seu direito à dignidade da pessoa humana e a presunção de inocência em relação à situação que lhe trouxe sofrimento e transtornos por um espaço temporal ou constante de exposição.

Cidadãos envolvidos em todo o enredo problemático desta apresentação midiática possuem seu direito a dignidade assegurada pela lei, a Constituição da 


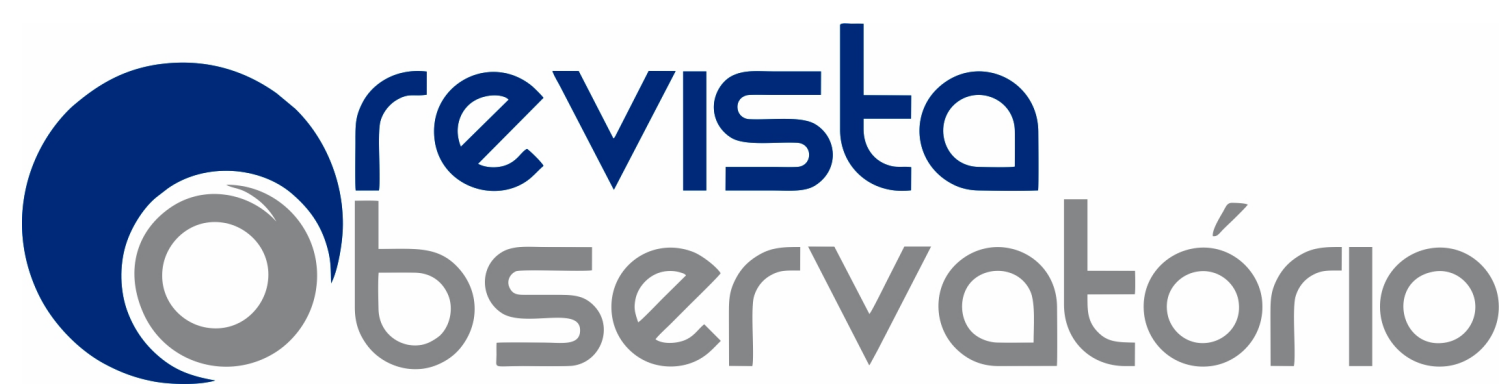

ISSN n² 2447-4266

Vol. 5, n. 6, Outubro-Dezembro. 2019

DOI: http://dx.doi.org/10.20873/uft.2447-4266.2019v5n6p429

República Federativa do Brasil de 1988 em seus artigos $1^{\circ}$, inciso III, e $5^{\circ}$, inciso X, assim como o artigo 21 do Código Civil Brasileiro.

A teoria do direito ao esquecimento não se sobrepõe ao direito a informação e da liberdade de expressão das pessoas e dos meios de divulgação da mídia. A frente destes fatos não se pode aceitar é a punição e condenação antecipada, a distorção da notícia e a manipulação condenatória popular das diversas classes sociais.

As diferentes classes sociais e econômicas emocionam-se e se compadecem com fatos descritos e contínuos de publicação nos meios midiáticos. O clamor social, a solidariedade pelas vítimas e seus familiares, compadecem e vão além do noticiário tomam para si as informações e relatos produzindo uma avalanche de diversos sentimentos.

Neste contexto fático todo nota-se que o suspeito/réu, não é visto como um cidadão, mas como se fosse um monstro que só deve ser lembrado pelo "mal" feito a coletividade.

O meio jornalístico principalmente aqueles tidos como sensacionalista estimulam todo o corpo social a nunca esquecer as matérias que mais deram ibope e consequentemente valor econômico a empresa, não é muito fácil para os leigos definir e entender o que é mídia. Esta pode ser compreendida segundo Lima como:

O conjunto de instituições que utiliza tecnologias específicas para realizar a comunicação humana. Vale dizer que a mídia implica na existência de um intermediário tecnológico para que a comunicação se realize. A comunicação passa, portanto, a ser uma comunicação mediatizada. Este é um tipo específico de comunicação que aparece tardiamente na história da humanidade e se constitui em um dos importantes símbolos da modernidade. Duas características da mídia são a sua unidirecionalidade e a produção centralizada e padronizada de conteúdo. Concretamente, quando falamos da mídia, estamos nos referindo ao conjunto das emissoras de rádio e de televisão (aberta e paga), de jornais e de revistas, do cinema e das outras diversas 


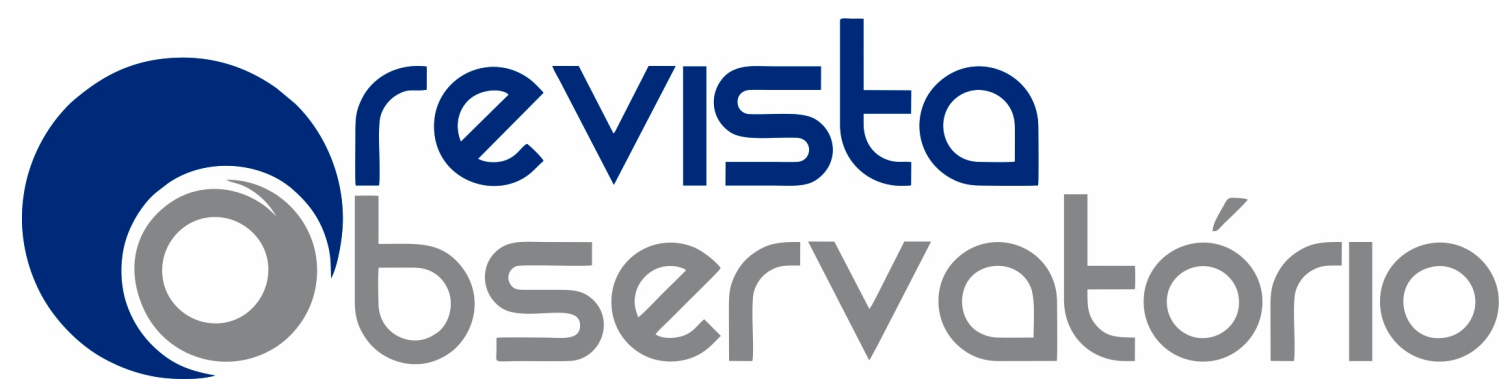

ISSN n² 2447-4266

Vol. 5, n. 6, Outubro-Dezembro. 2019

DOI: http://dx.doi.org/10.20873/uft.2447-4266.2019v5n6p429

instituições que utilizam recursos tecnológicos na chamada comunicação de massa. (LIMA, 2001, p.113).

Crimes tidos como graves e repugnantes pela população e pela mídia, disseminados pelos conteúdos corriqueiros das notícias os envolvidos têm o direito de serem esquecidos assim como seus protagonistas.

Nos dias atuais que as informações são como relâmpagos e sofrem modificações constantemente, a mídia deve permitir a sociedade esquecer e o protagonista viver dignamente sem ser rotulado, mesmo ainda passando pelo processo de pagamento da dívida com a justiça e a para com a sociedade julgadora leiga.

Usufruir do direito de resposta nunca é permitido, são acusados, condenados e sentenciados antes da conclusão do devido processo legal que thes dariam a oportunidade de colocar suas versões dos fatos e ter seu direito a presunção de inocência assegurado.

Conforme estabelecido na Lei 2.083 de 1953 em seu artigo 17, é assegurado o direito de resposta daquele que for acusado pela imprensa, mesmo a mídia ser um instrumento de dialética. Com base neste assunto supracitado, temos diversas decisões jurisprudenciais que atestam o direito ao esquecimento pelos meios de comunicação em massa, como exemplo do posicionamento Superior Tribunal de Justiça temos o Resp. 1660168/RJ, Rel. Ministra NANCY ANDRIGHI, Rel. p/ Acórdão Ministro MARCO AURÉLIO BELLIZZE, TERCEIRA TURMA, julgado em 08/05/2018, DJe 05/06/2018. A Ministra deixa claro que há de levar em consideração o alto grau de impacto midiático onde a mais alta relevância dos fatos pode causar a um indivíduo.

O tema sobredito é declarado algo muito polêmico em os juristas e doutrinadores, o Supremo Tribunal Federal (STF) em uma audiência pública a 


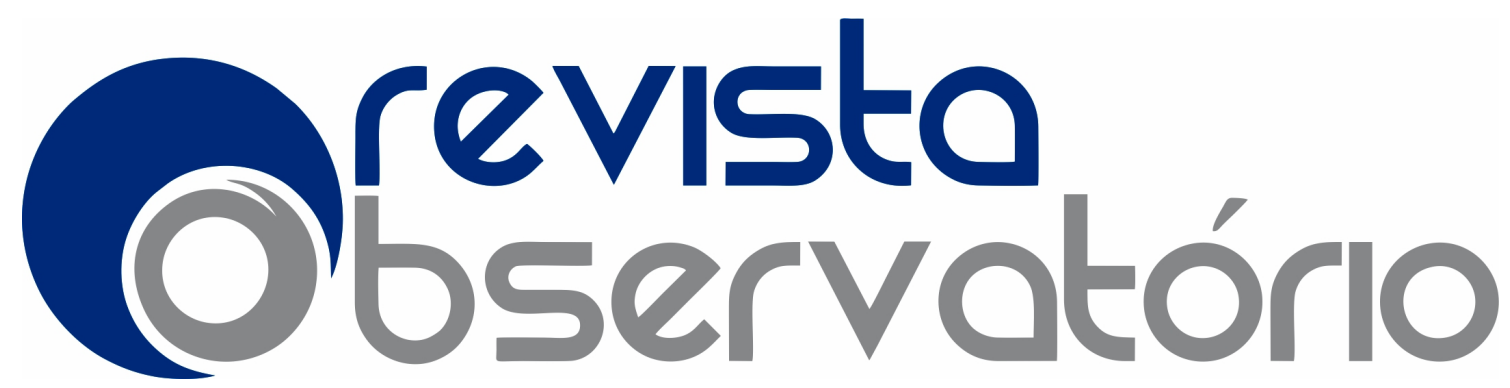

qual o ministro Dias Toffoli presidiu, classificaram o direito ao esquecimento em 03 (três) correntes cujo teor transcrevemos:

a) Posição pró-informação: é a teoria que direito ao esquecimento não existe, pois não está previsto na legislação da unidade federativa e que seria contrário ao direito de informação e divulgação de fatos importantes para a sociedade. Sendo que infringe o princípio a liberdade de expressão dos meios midiáticos nacionais, para sustentarem esse posicionamento utilização a ADI 4.815 do Supremo Tribunal Federal como jurisprudência base.

b) Posição pró-esquecimento: para estes doutrinadores o direito ao esquecimento existe e fere os direitos à intimidade, privacidade, presunção de inocência, o direito de resposta assim como outros direitos. A continuação de exposições constantes seria etiquetar uma pessoa como criminoso para o resto de sua vida, mesmo este cumprindo o pagamento da sua dívida para com a sociedade assim como a justiça.

c) Posição intermediária: a posição desta teoria é que há uma necessidade de equilíbrio entre o direito à informação da sociedade e da mídia com o direito à privacidade do indivíduo e seus entes envolvidos. A tese destes doutrinadores é fundamentada e defendida pelo Instituto Brasileiro de Direito Civil (IBDCivil).

Mesmo sendo um tema polêmico e bastante debatido, o STF vem enfrentando dificuldades nos julgamentos com grandes repercussões. Em um lado temos a mídia influenciadora e a população manipulada e punitiva e do outro o processo judicial, a presunção de inocência e os direitos do cidadão previstos em lei. 


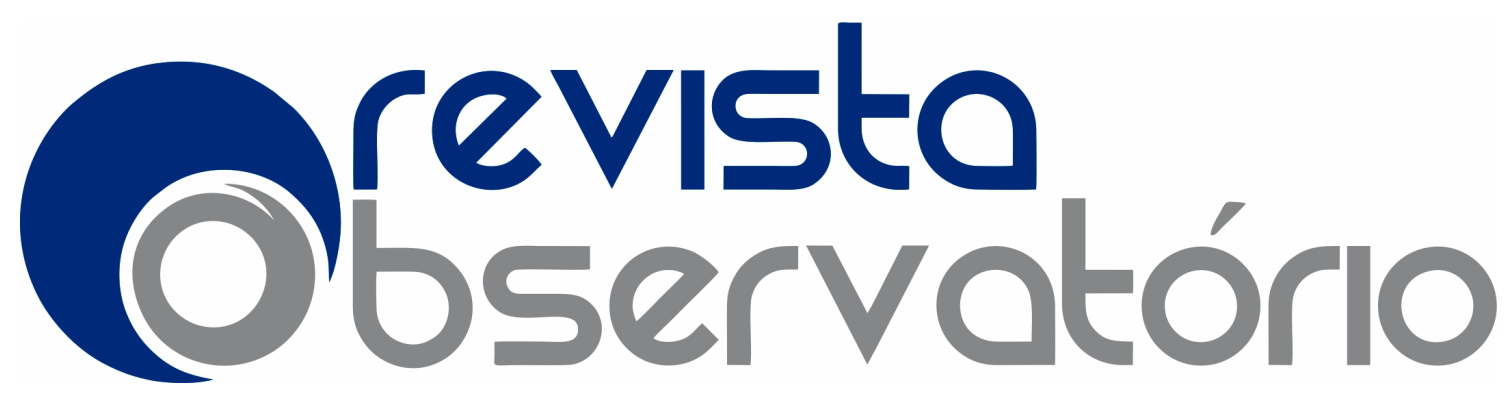

ISSN n² 2447-4266

Vol. 5, n. 6, Outubro-Dezembro. 2019

DOI: http://dx.doi.org/10.20873/uft.2447-4266.2019v5n6p429

Portanto, a mídia precisa ter como principal meio das produções valores éticos e sociais dos envolvidos no ato criminoso ou supostamente criminoso sem desprezar o princípio da dignidade humana.

\section{Considerações Finais}

A questão inicial que orientou esta pesquisa foi compreender que a mídia possui uma grande influência na vida das pessoas. Vivemos em um tempo que as notícias se propagam rápido, tomam proporções gigantescas e alcançam todas as classes sociais pelos mais diversos meios tidos como de reprodução e compartilhamento da informação em massa.

Pode-se então perceber que o direito à informação e à liberdade de expressão é a sustentação da mídia para o espetáculo que proporciona a população, implementando uma visão segundo a visão econômica e atrativa ao público-alvo. Quando uma matéria é noticiada logo uma forma de emoção nos envolve e praticamente sentimos o sofrimento da vítima, e a imagem negativa que nos vem à cabeça é do "monstro" do ato criminoso.

Partimos do pressuposto que um fato ocorra, este toma grandes proporções e interesse da sociedade. Será lançado a todo instante, chamadas sobre o tema e os principais agentes envolvidos, a partir desse momento, vidas podem ser destruídas mesmo que não haja culpa alguma apenas especulações midiáticas que refletem na visão e condenação popular. O posicionamento da sociedade acaba indo parar nos tribunais que são precisados a dar uma rápida resposta aos mais interessados na punição dos possíveis indivíduos. Mesmo havendo a certeza da execução dos episódios narrados pelos telejornais, jornais e dispositivos de mensagens instantâneas não justifica condenar antes do devido processo legal e muito menos agir com as próprias mãos a fim de conseguir o que é tido como "justiça" por algumas pessoas. 


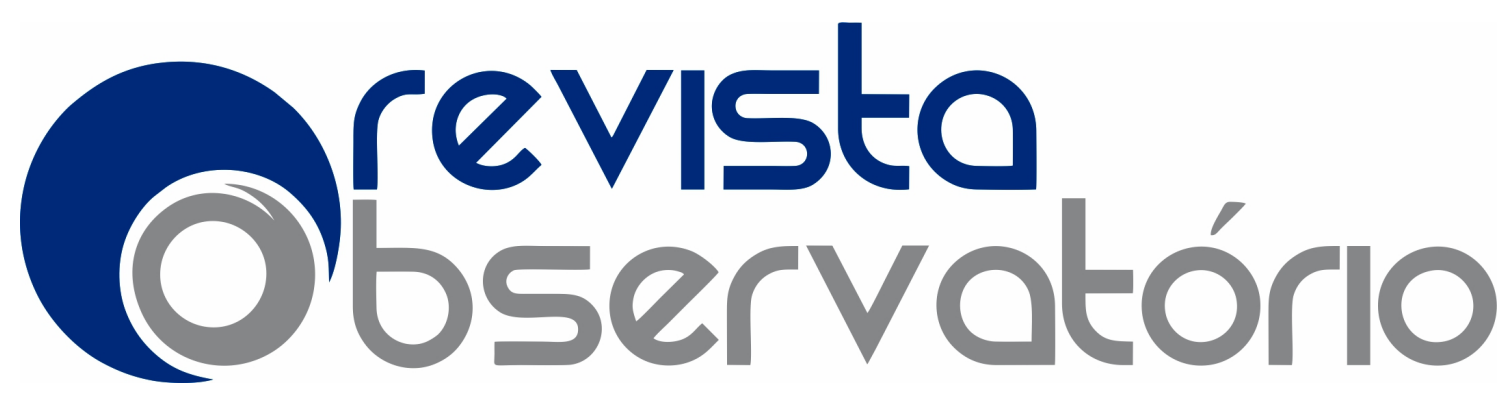

DOI: http://dx.doi.org/10.20873/uft.2447-4266.2019v5n6p429

Dado o exposto acima conclui-se que a garantia do direito fundamental a liberdade de expressão e informação não pode se sobressair sobre os direitos e garantias individuais, ambas possuem a mesma força perante a legislação e precisam ser respeitadas para o efetivo cumprimento da justiça.

A veiculação das mídias sobre assuntos polêmicos sempre vai existir como já explanado possui um caráter financeiro e empresarial envolvido. O judiciário e o Estado precisam inserir mecanismos aos meios de comunicações sejam o mais democrático e fiel possível, para que não haja invasão da intimidade pessoal, violação da privacidade do acusado e afetar sua honra.

Em suma, o que é necessário é estabelecer um equilíbrio entre as notícias divulgadas e os direitos de cada indivíduo em seus devidos casos, sem relembrar os fatos similares daqueles que já cumpriram seu dever com a justiça e com a sociedade, dando-lhes o direito ao esquecimento do acontecido. Antes de qualquer coisa a presunção de inocência deve estar sempre em primeiro lugar, para a proteção da pessoa, da sociedade e da justiça.

\section{Referências}

ALVIM, J. E. Carreira. Elementos de teoria geral do processo. 7. ed. Rio de Janeiro: Forense, 1999.

AMARAL FILHO, O. A ESPETACULARIZAÇÃO E CONEXÃO DA POLÍTICA E DA CIDADANIA NO ESPAÇO PÚBLICO MIDIATIZADO. Revista Observatório, v. 4, n. 6, p. $442-474,8$ out. 2018.

AZEVEDO, Fernando Antonio. Mídia e democracia no Brasil: relações entre o sistema de mídia e o sistema político. Universidade Federal de São Carlos. 2006, p. 97.

BECCARIA, Cesare. Dos delitos e das penas. Tradução de Flório de Angelis. Bauru, SP: Edipro, 1999. 


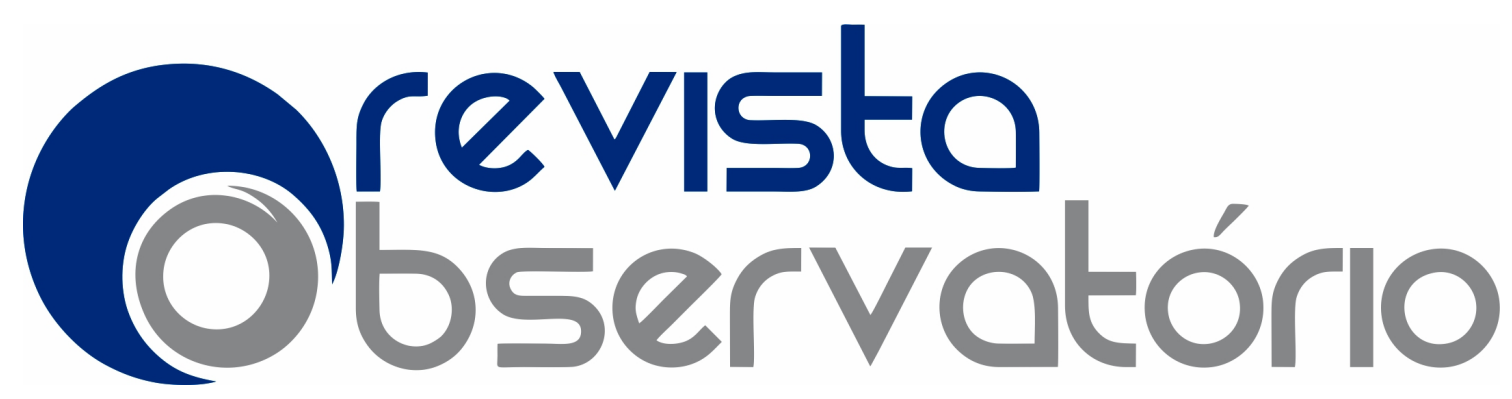

ISSN n² 2447-4266

Vol. 5, n. 6, Outubro-Dezembro. 2019

DOI: http://dx.doi.org/10.20873/uft.2447-4266.2019v5n6p429

BRASIL. [Constituição (1988)]. Constituição da República Federativa do Brasil de 1988, Brasília, DF: Diário Oficial da União, 05 dez. 1988. Disponível em: http://www.planalto.gov.br/ccivil_03/constituicao/constituicao.htm. Acesso em: 29 ago. 2019.

Decreto-Lei no 2.848, de 7 de dezembro de 1940. Código Penal, Brasília, DF: Diário Oficial da União, 31 dez. 1940. Disponível em: http://www.planalto.gov.br/ccivil_03/constituicao/constituicao.htm. Acesso em: 29 ago. 2019.

BRAMBILLA, A. M. HOMOGENEIDADE E ENDOGENIA NOS INTERESSES DE JORNALISTAS DES-CONECTAM VALOR NOTÍCIA E POPULAÇÃO. Revista Observatório, v. 4, n. 4, p. 420-444, 29 jun. 2018.

CARVALHO FILHO, Luiz Francisco. Mídia, violência e sistema penal. Revista Brasileira de Ciências Criminais. São Paulo, v. 42, p. 226, 2003.

CHAUÍ, Marilena. Simulacro e poder: uma análise da mídia. São Paulo: Fundação Perseu Abramo, 2006, p. 57.

DOTTI, René Ariel. As dez pragas do sistema penal brasileiro. In: TUBENCHLAK, James (Org.). Doutrina: v. 11, Rio de Janeiro: ID, 2001, p. 288.

FERRAJOLI, Luigi. Direito e razão: teoria do garantismo penal / Luigi Ferrajoli. São Paulo: Editora Revista dos Tribunais, 2002.

FOUCAULT, Michel. Vigiar e Punir: nascimento da prisão; tradução de Raquel Ramalhete.42. ed. Petropólis, RJ: Vozes, p. 9. 2014.

FREUD, S. O mal está na civilização (1930-1936). Obras completas. Volume 18. Trad. de Paulo César de Souza. São Paulo: Companhia das Letras, p. 28/29.2010.

GOMES, Luiz Flávio; ALMEIDA, Débora de Souza. Populismo Penal Midiático Caso mensalão, mídia desruptiva e direito penal crítico. Saraiva, p. 104. 2013.

MARTINS NETO, João do Passos. Fundamentos da Liberdade de Expressão. Florianópolis: Insular, p. 2. 2008. 


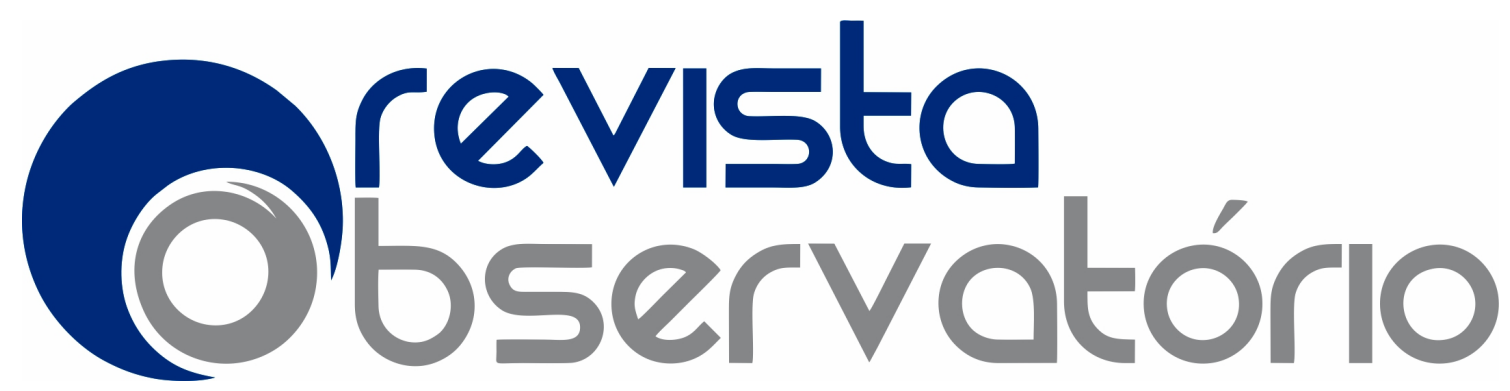

ISSN n² 2447-4266

Vol. 5, n. 6, Outubro-Dezembro. 2019

DOI: http://dx.doi.org/10.20873/uft.2447-4266.2019v5n6p429

MARTINS, J. L.; SILVA, B. D. DA; SILVA, V. C. Novos problemas, outras narrativas, entrevista com Pedro Demo. Revista Observatório, v. 3, n. 4, p. 639-644, 1 jul. 2017.

MARTINS, J. L.; SILVA, V. C. DA. AVALIAÇÃO DA DIALOGIA EM FÓRUNS DE CURSO ONLINE: processo dialógico na formação de comunidades de sentidos. Revista Observatório, v. 3, n. 4, p. 232-255, 1 jul. 2017.

MASCARENHAS, Oacir Silva. A influência da mídia na produção legislativa penal brasileira. In: Âmbito Jurídico, Rio Grande, XIII, n. 83, dez. 2010. Disponível em: $<$ http://www.ambitojuridico.com.br/site/?n_link=revista_artigos_leitura\&artigo_i $\mathrm{d}=8727$ \&revista_caderno=3>. Acesso em: 5 mai. 2019.

NERY, Arianne Câmara. Considerações Sobre o Papel da Mídia no Processo Penal. Monografia de conclusão de curso. Pontifícia Universidade Católica-PUC. p. 68 2010. Disponível em: < http://www.maxwell.vrac.puc-rio.br/16733/16733.PDF>. Acesso em: 20 abr. 2019.

NOGUEIRA, L. A noticiabilidade a partir do audiovisual: da mídia tradicional à recirculação em redes sociais digitais. Revista Observatório, v. 4, n. 4, p. 445-467, 29 jun. 2018.

NUNES, Poliana Rollo. Jornalismo de Revista: Análise dos critérios de noticiabilidade das capas da revista Época. Monografia de Conclusão de Curso bacharelado e comunicação social - habilitação em jornalismo. Centro Universitário de Belo Horizonte UNI-BH. Belo Horizonte, p 53. 2008. Disponível em: < http://convergencia.jor.br/bancomonos/2008/poliana_nunes.pdf>. Acesso em: 28 abr. 2019.

OLIVEIRA, A. M.; MACHADO, M. Adolescência, cultura e sociedade do espetáculo. Revista Observatório, v. 4, n. 2, p. 458-479, 1 abr. 2018.

PELUSO, Vinicius de Toledo Piza. Introdução às Ciências Criminais. Juspodivm, p. 209. 2015.

SÁ, Alvino Augusto de; SHECARIA, Sérgio Salomão (organizadores). Criminologia e os problemas da atualidade. São Paulo: Atlas. 128.2008. 


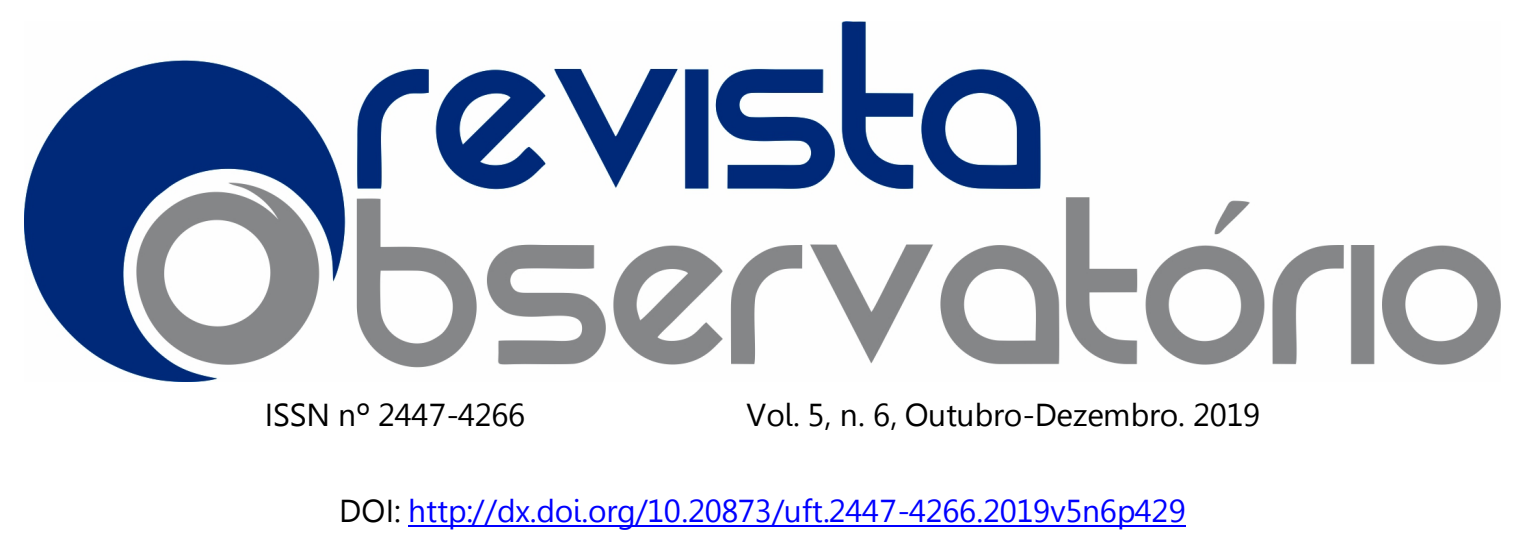

SANTOS, E. R. DOS; GUAZINA, L. S. O uso das fontes nas notícias sobre o processo de impeachment: uma análise da cobertura realizada pelos jornais Folha de $\mathrm{S}$. Paulo e a Tarde (BA). Revista Observatório, v. 3, n. 6, p. 612-635, 1 out. 2017. SEIXAS, L. VALORES NOTÍCIA: uma proposta de análise. Revista Observatório, v. 4, n. 4, p. 334-366, 29 jun. 2018.

SOUZA NETTO, José Laurindo de. A Solução do Conflito entre a Liberdade de Expressão e o Direito à Privacidade Diante da Pretensão de Incensurabilidade Prévia da Imprensa. In: REVISTA Escola da Magistratura do Paraná / Medeiros, Marco André (Org.). Curitiba: M. Medeiros Editora, p. 74. 2011.

TELLES, Renato. A efetividade da matriz de amarração de Mazzon nas pesquisas em Administração. Revista de Administração, São Paulo v.36, n.4, p.64-72, outubro/dezembro 2001.

TEIXEIRA, I.; DA SILVA, V. C.; MARTINS, J. L. A CONVERGÊNCIA MIDIÁTICA E AS TECNOLOGIAS MÓVEIS PÓS-BOLONHA: NOVAS PRÁTICAS SOCIAIS. Revista Observatório, v. 3, n. 6, p. 229-247, 1 out. 2017.

TEIXEIRA, I.; SILVA, P. C. DA; SOUSA, S. L. DE; SILVA, V. C. DA. NOMOFOBIA: os impactos psíquicos do uso abusivo das tecnologias digitais em jovens universitários. Revista Observatório, v. 5, n. 5, p. 209-240, 1 ago. 2019.

VIZEU, A.; LEITE, F. DECIDINDO O QUE É NOTÍCIA: 20 anos depois. Revista Observatório, v. 4, n. 4, p. 284-307, 29 jun. 2018.

XAVIER, C.; VERNER, A. VALORES-NOTÍCIA E INTERNET: Um estudo exploratório sobre as notícias mais acessadas do portal aRede. Revista Observatório, v. 5, n. 4, p. 438-462, 1 jul. 2019. 